\author{
Удк 355.01 \\ DOI: https://doi.org/10.18485/fb_iss.2020.1.ch9
}

\title{
НОВИ РАТОВИ И ИЗАЗОВИ КЛАСИЧНОЈ СТРАТЕГИЈСКОЈ МИСЛИ
}

\author{
доц. др Милан Миљковић ${ }^{1}$
}

\section{Апстракт}

Недавно вођени сукоби били су нешто сасвим ново у пракси вођења ратова, што је утицало да се у научној јавности покрене дискусија око новог дефинисања самог појма и карактеристика савременог рата. Последично, у савременој војној теорији сусрећу се таква одређења које говоре о „новој генерацији ратовања“ у којима оружана борба није његов обавезни атрибут. Наведене теорије „новог рата“ привукле су бројне присталице, али су уједно отвориле нова питања, јер су између осталог учиниле постојеће међународно хуманитарно право застарелим и неупотребљивим. На изазову се нашла и стратегија, научна теорија и пракса од највишег државног и војног значаја која треба да пружи водиље и створи услове за остварење политичких, економски и одбрамбених интереса нације. Приоритетни задаци стратегије као науке и даље су истраживање нових форми конфронтације између држава, као и разрада делотворних начина супротстављања њима, креирање сценарија и дугорочних прогноза развоја стратегијске ситуације. Са друге стране, већ дуго у западној стратегијској мисли под утицајем, војно-технолошке револуције постоји нови приступ за формулисање нових матрица у стратешким оквирима. С тим у вези може да се постави истраживачко питање: да ли је ефикасније у току израде и реализације стратегијских докумената применити приступ заснован на новој филозофији и динамичном приступу. Компаративна анализа обележја „класичне“ стратегијске мисли и одредница појединих нових америчких војних стратегија и стратегије детерминистичких хаоса указује на то да је у обликовању стратегијске стварности значајнија улога стратегије од прогнозирања обележја и начина одбране у будућим конфликтима.

Кључне речи: класична стратегија, динамична стратегија, обликовање стратегијске стварности

1 Катедра стратегије Школе националне одбране Универзитета одбране Министарства одбране Србије, Е-пошта: sno.kstrategije@sno.uo.mo 


\section{ПОЈЕДИНЕ КАРАКТЕРИСТИКЕ „НОВЕ ГЕНЕРАЦИЈЕ РАТОВА“}

Недавни сукоби, иако су били засновани на познатим стратегијама, њихов обим и истовремена операционализација асиметричних поступака, били су нешто сасвим ново у војној пракси. Савремени војни теоретичари због тога указују да је главна разлика између традиционалне и „нове генерације ратовања“ концептуални прелазак: 1) од директног уништења до директног утицаја; 2) од директног уништења противника ка његовом унутрашњем пропадању; 3) из рата оружјем и технологијом у рат кроз културу; 4) из рата конвенционалним снагама у рат специјално припремљеним снагама и комерцијалним или нерегуларним групацијама; 5) од традиционалног бојишта у три димензије до рата информацијама (психолошки рат и рат перцепције); 6) од директног сукоба до бесконтактног рата; 7) из сегментног ратовања у тотални рат; 8) из рата у физичком окружењу до рата у људској свести и у сајбер простору; 9) од симетричног до асиметричног рата - истовременом и усклађеном применом политичких, економских, информационих, технолошких и еколошких кампања; и 10) од рата у одређеном временском периоду до стања перманентног рата као природног стања у животу сваке нације. ${ }^{2}$

У категорију савременог ратовања сврстава се „хибридно ратовање“, које се повезује са циљем да се искористе рањивости противника, а мање са циљем да се физички униште његове оружане снаге. 3 У ширем смислу, хибридно ратовање може се разумети као креативна комбинација цивилних и војних капацитета и средстава који се ангажују на синхронизован начин. ${ }^{4}$ Политички циљ државних или недржавних актера који воде хибридни рат је очување или свргавање режима противника, али и повећање стратешких опција и моћи у међународним односима. Западни теоретичари наводе да стратегија употребе хибридног ратовања, које користе неке државе, постаје на крају „велика стратегија“ тих актера. 5

Западни војни експерти закључују да хибридно ратовање карактеришу следећи принципи:

1. Потпуно упознати и анализирати противника користећи научне методе. Циљ је да се идентификују и искористе рањивости противника, посебно на

2 Janis Berzins, „Russia's New Generation Warfare”, The Potomac Foundation, October 11, 2016, http//www.thepotomacfoundation.org/The New Generation of Russian WarfareThe Potomac Foundation.htm

3 Uwe Hartmann, The Evolution of the Hybrid Threat, and Resilience as a Countermeasure, NATO Defense College, Rome, Research Paper No. 139 - September 2017.

4 Frank Hoffman, "Conflict in the 21st Century: The Rise of Hybrid Wars," Potomac Institute for Policy Studies , Arlington, Virginia, December 2007, https://www.potomacinstitute.org/images/stories/publications/potomac_hybridwar_0108.p df

5 Термин „велика стратегија“ повезује се британским војним стратегијским мислиоцем Базилом Лиделом Хартом (Basil Liddell Hart). 
стратешком нивоу.

2. Развити кохерентне стратегије: повезивањем свих војних (конвенционалних/ирегуларних/нуклеарних) и цивилних инструмената државне структуре, као и свих нивоа командовања (стратешки, оперативни и тактички) под јединствену националну команду која развија, примењује и прилагођава мање стратегије у „велику стратегију“.

3. Стратегије спроводити двосмислено. Бити непредвидив, опортунистичан у акцијама и флексибилно прилагођавати своје стратегије да би се изашло у сусрет непредвиђеним могућностима и ризицима.

4. Оспоравати постојећу парадигму ратовања. Уздржавати се од званичног проглашења почетка и завршетка рата. Конвенционални рат би требало да траје што краће, док хибридна претња може да траје непрекидно.

5. Користити време као стратегијску предност, употребом скривених стратегија, стратегијског прикривања и обмањивања и стратегијског изненађења.

6. Користити оружане снаге без ризика од стратегијског пораза. Користити војна средства и акције на војном плану за упућивање претњи и притисака према цивилним актерима противничке стране, као и за одвраћање противника од могућих војних акција.

7. Тежити да се постигне доминација у информационом простору у односу на противника, и то на свим нивоима ратовања (стратегијском, оперативном и тактичком), путем примене комплексних информационих операција.

Може се закључити да хибридно ратовање у конвенционалном сукобу није намењено за директно уништавање противничких оружаних снага, већ, између осталог, и за наношење удараца противничкој војној и цивилној информационој и комуникацијској структури, чиме се актуелизује место и улога информационих операција у овој врсти ратовања.

На основу тога може да се каже да је дошло до квалитативне промене битних, суштинских, стратешких одлика „старога“ модела оружаних сукоба. Стари модел почива на спором, али дефинитивном повлачењу са сцене некада јединог и неприкосновеног актера - државе. Класичног рата као „борбе између две или више држава посредством њихових оружаних снага са циљем да се надвлада супарник и наметну услови мира које победник жели“више нема.

Наведене теорије „новог рата“ привукле су броје присталице, али су уједно отвориле нова питања, јер су, између осталог, учиниле постојеће међународно хуманитарно право застарелим и неупотребљивим. 6 Тај нормативни оквир, особито онај његов део који треба да уреди односе страна у сукобу, превасходно је креиран с обзиром на „старе“ сукобе. Право оружаних сукоба сада је готово у целини уздрмано успоном „новог типа ратовања“.7 Пред изазовом се нашла и

6 Весна Кнежевић-Предић, Нови ратови v. старо право, Извод из књиге: Оглед о међународном хуманитарном праву, Чигоја штампа, Београд, 2007. стр. 9-37, Приступљено: 14.8.2020, https://www.rastko.rs/rastko/delo/14837

7 Brooks, R. E., War Everywhere: Rights, National Security Law and the Law of Armed Conflict in the Age of Terror, UPLR, Vol. 153, No. 675, 2004. p. 746 
стратегија, научна теорија и пракса од највишег државног и војног значаја, која треба да укаже на начине и створи услове за остварење политичких, економски и одбрамбених интереса нације.

\section{ОДРЕДНИЦЕ КЛАСИЧНЕ ТЕОРИЈЕ СТРАТЕГИЈЕ}

Не постоји иоле важнији друштвени или национални интерес који не захтева повезивање и усклађеност деловања свих субјеката једног друштва и државе, у погледу циљева, средстава и начина остварења интереса. 8 Управо тај оквир у коме се постављају циљеви, носиоци, средства и начини обезбеђује јединство заједничког, ради задовољења најважнијих друштвених (заједничких) интереса, приближава нас теорији и пракси коју једном речју називамо стратегија.

При објашњавању појма стратегије, требало би на почетку навести ставове Живојина Мишића, изнете у делу „Стратегија - вештина ратовања“, у коме Мишић излаже да у војној литератури ни тада није било рашчишћено питање, да ли је стратегија наука или је само вештина. Мишић наводи да су мишљења многих војних писаца по овом питању не само различна, него су дијаметрално противна. Мишић појашњава да су основна начела ратовања, којих се придржавао Наполеон, добила општи назив принципа, којима је даван чак и значај закона који се не мењају. Међутим, ако се размотри посебице сваки од тих принципа, лако ћемо се уверити да ти принципи имају само значај примера, угледа, савета, упута, који могу да се примењују само у извесним случајевима ратних догађаја и прилика, према чему је и значај тих принципа сасвим услован. Уколико се који од ових принципа могу да примене у датом тренутку и у датој прилици на војишту и бојишту, утолико ти принципи добијају силу природног закона за сваку борбу. ${ }^{9}$

Одговарајући на питање „шта је онда Стратегија у самој ствари“, Мишић појашњава да је тешко спорити да је циљ Стратегије да објасни основна начела која иду на то да се одржи победа над непријатељем. Закључује да се „из ових разматрања може извести закључак да је суштина Стратегије у томе да се правилно схвате и познаду природне основе сваке борбе“.10

При разматрању питања важности стратегије као теорије или стратегије као праксе, требало би навести и ставове које наши војни историчари доводе у везу са Радомиром Путником¹, у којима се наводи да право знање стратегије није у

8 Сава Савић, Стубови европске безбедности на почетку 21. века - НАТО и Европска унија, Медија Центар Одбрана, Београд, 2013, стр. 55.

9 Живојин Мишић, Стратегија - вештина ратовања, Нова штампарија Давидовић, Београд, 1907, стр. 10-15.

10 Исто.

11 Велимир Иветић у свом докторском раду „Политичка улога министара војних Краљевине Србије од 1903. до 1914. године“ на 213. страни наводи до сада непознати податак да је Путник био аутор и данас поучног чланка Изобласти ратне вештине. Тежиште модерне стратегије, објављеног у Ратнику 1911. године, у бројевима за август и септембра (књ. 71, св. 1 и 2) и потписао се са Mahadöh (у преводу: Велики дух - 
смислу теорије, него је право знање стратегије у способности да се проникне у стратегијску ситуацију операције у целини, да умемо умовати у области објективне, а не школске ситуације и стратегије, да радимо на карти и у кабинету, и да се смемо решавати на крупне стратегијске кораке и циљеве, једном речју да смо духовно смели.

Правилно схватање стратегијске ситуације једне операције јесте први корак за успешно решавање стратегијског проблема. ${ }^{12}$ Савремени теоретичари кажу да је појам стратегија давно променио садржај и обим у односу на традиционално и класично његово поистовећивање са војном стратегијом. У Војној енциклопедији стратегија се дефинише као „систем научних знања и вештина (теорија и пракса) о припремању и вођењу рата и употреби силе ради остваривања одређених војних, политичких или економских циљева“. Дефинисано је да стратегија као наука за предмет узима „основне закономерности рата, посебно његовог суштинског елемента - оружане борбе, али и других облика испољавања војне силе“. 13

Данас је стратегија далеко шири систем који, у теоријском и практичном смислу, захвата све основне функције државе у миру и рату. Првобитно значење стратегије је еволуирало од вођења војске до вештине вођења рата, а данас она представља систем знања, правила, принципа и закона којима се захватају стратегијски сукоби, у целини, ради постизања стратегијских циљева.

Стратегија државе односи се на многоврсне друштвене појаве и људско деловање у њима, па се грана на посебне и појединачне стратегије. Стратегија државе, или општа стратегија је самостална наука и истовремено умешност или вештина државништва, као и инструмент државне политике, тј. скуп правила о оптималном управљању државом, стицању моћи и ангажовању расположивих снага и ресурса ради остваривања циљева политике. ${ }^{14}$

Однос стратегије и моћи остварује се преко конверзије моћи - одређивањем путање од ресурса до исхода у промени понашања - и то јесте кључна улога стратегије, пошто поседовање ресурса моћи не гарантује да сте увек постигли жељени исход. На пример, у погледу ресурса, Сједињене Државе су биле много моћније него Вијетнам, па ипак су изгубиле рат. Конверзија ресурса у остварену моћ, у смислу постизања жељених исхода, захтева добро постављене стратегије и вешто вођство. Стратегије представљају програмска становишта за достизање и остваривање - конверзију моћи у свим областима друштвеног живота, односно испуњење националних интереса.

У страној литератури о државној стратегији, британски аутори углавном користе појам велика или висока стратегија. Лидел Харт је у познатом делу „Стратегија

прим. В.И.). Вероватно због анонимности аутора чланак није привукао заслужену пажњу

12 Маладох , Лист Ратник, Година LXXI, Свеска 1, Август 1911, стр. 7.

${ }_{13}$ Војна енциклопедија, друго издање, ВИЗ, Београд, 1975, стр. 171.

${ }^{14}$ Миланко Зорић, „Теоријске основе опште стратегије“, Војно дело, 1/99, стр 73-74. 
посредног прилажења“, увео појам „висока стратегија“, којим се означава политика која управља целином напора и ресурса нације и државе у миру и рату. Суштински, ради се о стратегији државе, где се интегришу напори у функцији остварења стратегијског циља. ${ }^{15}$ Харт такође каже да је задатак високе стратегије да све изворе једног народа координира и упућује ка постигнућу политичког циља рата, циља који одређује национална политика. ${ }^{16}$ Ако се изузме наведено сужавање велике стратегије на период рата, важно је напоменути координациону улогу велике, односно, државне стратегије, у односу на све елементе националне моћи. Такође, њен смисао је да усмерава и обезбеђује јединство свих аспеката националне политике, заправо посебних стратегија. ${ }^{17}$

У америчкој литератури реч стратегија се углавном везује за државу и силу и за спровођење политике путем одређених делатности, метода и поступака. Поједини амерички аутори, уместо израза национална или глобална стратегија, користе синтагму велика или висока стратегија. Према Едварду Мид Ерлу, велика стратегија је део државничке вештине у миру и рату, односно, „вештина владања и искоришћавања свих средстава којима један народ или коакиција народа располажу у датом тренутку, подразумевајући ту и оружану силу, са циљем да се његови битни интереси одрже и заштите од непријатеља, стварног или могућег или вероватног“.18

Француски аутори највиши тип стратегије називају „тотална стратегија“. Тако Бофр у делу „Уводу у стратегију“ упозорава да су све стратегије у прошлости биле тоталне (националне, стратегије државе), али да је њихов тоталитет био засењен сјајем битака које су добијали знаменити стратези, односно њиховим војним аспектом. ${ }^{19}$ Улога тоталне стратегије, по Бофру, је да одређује појединачне задатке и комбинације различитих „генералних стратегија“ у политичком, економском, дипломатском и војном погледу. Она синтетизује онолико генералних стратегија колико има грана и области државне делатности. Интересантно је да је стратегија за Бофра вештина, а не наука, јер се стратегија не може потпуно ослонити на листу теоријских правила. Са друге стране, наводећи да је стратегија „дисциплина мишљења која је неопходна владајућим круговима, односно да је она систем мишљења који може послужити као практичан водич за остваривање политике“20, Бофр ипак указује да се стратегија као вештина спроводи уз поштовање и придржавање одређених водиља.

Други француски аутор, Лисјен Поатје, сматра да је стратегија „наука и вештина схватања (теорија) и сталног управљања (пракса) поступком снага (за време мира, кризе и рата), постојећих и потенцијалних, чије капацитете генерише нека група (на пример национална држава), да се то оствари, у фиксираном просторно-

\footnotetext{
15 Лидел, Харт, Стратегија посредног прилажења, Војно дело, Београд, 1952, стр 199.

16 Исто.

17 „British Defence Doctrine“, MoD, Whitehall , London, 1996, p.18

18 Едвард Меад Ерл, Творци модерне стратегије, Војно дело, Београд, 1952, стр. 2-3.

${ }^{19}$ Анре Бофр, Увод у стратегију, ВИЗ, Београд, 1968.

20 Миланко Зорић, „Теоријске основе опште стратегије“, Војно дело, 1/99, стр 78-79.
} 
временском оквиру, упркос супростављању противника (што значи да морају да постоје варијанте за испуњавања циљева стратегије и у најтежим условим), и уз помоћ савезника, а према правилима економичности управљања сваком заједничком акцијом. ${ }^{21}$

Cтратегија се у домаћој литератури дефинише на различите начине. Душан Вишњић износи став да је стратегија државе системски напор теоријског ума стратегичара (мислилаца стратегије) и практичног ума стратега (реализатора стратегијских планова посебних стратегија) да осмисле живот државе - нације, како у целини, тако и у посебним областима стратегијског мишљења и деловања. Реч је о најодговорнијем облику критичке друштвене науке који, никад није као политика, покидао везе између знања и морала, односно између истине и етичких вредности. Вишњић објашњава да је основна сврха теорије опште стратегије, тј. теорије стратегије државе, постизање оптималне ефикасности стратешке праксе, уз задовољавајући ниво контроле стихијности стратегијских процеса, како сопствених, тако и свих оних који би могли да утичу на стратегијску стварност државе - нације. 22

Сумирајући наведене дефиниције, може се закључити да је стратегија процес, стално прилагођавање променљивим условима и околностима у свету, у којем су шанса, несигурност и двосмисленост доминантни. ${ }^{23}$ Када се овај став повеже са ставом Молткеа да је стратегија „вештина делања под притиском и најтежих околности“, може се оценити да је стратегија државе и теорија и пракса (вештина) непрекидног и упорног испуњавања националних циљева и интереса, и под најтежим околностима, које су често несигурне, нејасне и двосмислене, тј. прилагођавање метода испуњавања ових циљева услед промене услова и околности, како спољашњих, тако и унутрашњих. У овом процесу, улога стратегије је да уз помоћ теорије и праксе, праћењем и деловањем у циљу иницирања позитивних промена у стратешкој стварности, ствара повољне услове и користи шансе за реализацију циљева којима се испуњавају национални интереси. Улога стратегичара је да те шансе предвиди, уочи и да их предочи стратегу ради њиховог искориштења и обликовања стратегијске реалности коришћењем елемената националне моћи. Значи, како каже Едер (Erich Eder), стратегија је активност којом се предвиђени циљеви претварају прво у могућности, а онда и у стварност. 24

Треба напоменути да је стратегија како теорија, тако и пракса, пракса, умешност или вештина државништва и средство политике, тј. укупност правила о практичним активностима и функцијама највиших органа државне власти (или стратега) у свим областима. То је умеће и сврсисходан и ефикасан начин

${ }^{21}$ Lucien Poirier. Essais de stratégie théorique, FEDN, Paris, 1982, pp 127-128.

22 Душан Вишњић, „Општа стратегија или стратегија државе - нације“, Војно дело, зима/2011,стр 393.

23 Мала енциклопедија, Просвета, ор. cit., p. 2.

${ }^{24}$ Eder, Erich: Definition und Gebrauch des Begriffes «Strategie», Österreichische Militarische Zeitshrift, 2/98, s. 121-128. 
примењивања општих правила на конкретне случајеве. Смисао опште, тј. државне стратегије као инструмента државне политике и практичне делатности јесте опстанак и развој државе и нације, пораст државне снаге и националне моћи и способности да се заштити и одбрани од свих спољних, унутрашњих и комбинованих претњи и облика угрожавања.

Као инструмент државне политике, стратегијом као документом, остварује се повезивање постављених националних циљева, с једне стране, и расположивих средстава за њихово постизање, с друге стране.

У делу „Стратегија“25 совјетског стратегичара Свећина упозорава се на обавезу извршилаца у области (било које) стратегије да не губе из вида стратегију непријатеља. Ако бисмо још даље анализирали тај став, дошли би смо до сазнања да је свака стратегија, по природи ствари, у одређеном обиму и антистратегија.

\section{ОБЈЕКАТ, ПРЕДМЕТ И КЛАСИФИКАЦИЈА СТРАТЕГИЈЕ}

Први елемент теоријског одређења појма јесте објекат стратегије. Формално (не и формалистички) у стратегијском искуству је пет трајних структурних елемената објекта стратегије: (а) фундаменталне екстерне релације једне државе као субјекта стратегијских односа с другим сличним субјектима и интерне релације са сопственим подсистемима, (б) сукоби, (ц) вредности и/или интереси, (д) моћи и силе и (е) стратегијска знања. ${ }^{26}$

Други елемент теоријског одређења јесте предмет стратегије. Представу о предмету у свом делу др Душан Вишњић своди на два, условно говорећи, категоријална појма: (а) стратегијска стварност и (б) предмет стратегије. Стратегијска стварност државе је основа њене целокупне стварности. Суштину државе чине њени интерни и екстерни односи са другим државама. Та стварност није само оно што је реално дато у простору и времену, него и оно виртуелно, то јест потенцијално у односима стратегијских ентитета и диспозиционо у психичкој сфери стратегичара и стратега двају сукобника. Предмет опште cmpameгuje јесу комплекси међусобних проблема који настају у интеракцији сукобљености процена стратегијских ентитета. Исходиште стратегијских проблема у подједнакој мери је научно-теоријско и праксеолошко. ${ }^{27}$

Трећи елемент јесу опште основне методе стратегијских истраживања: (а) стратегијско узроковање и (б) стратегијско предвиђање. ${ }^{28}$

И док се дефиниција односи на садржај појма, класификација се односи на његов обим. Један од прихватљивијих је онај критеријум класификације који се односи

\footnotetext{
25 Види шире у: Свећин, А., А., Стратегија, Војно дело, Београд, 1956.

26 Душан Вишњић, „Општа стратегија или стратегија државе-нације“, Војно дело/зима 2011, стр 397, 399.

27 Душан Вишњић, стр. 399.

${ }^{28}$ Александар А. Свећин, Стратегија, ВИЗ, Београд, 1956. стр. 36-58.
} 
на основна подручја државне делатности, односно основне функције државе. Једна стратегија била би општа или стратегија државе, а „специјализоване“ стратегије би биле посебне и појединачне државне стратегије. Према том критеријуму, појам стратегија државе, може се класификовати на следеће појмове класе или врсте: политичка стратегија, економска стратегија и војна стратегија. Као и приликом дефинисања појма, и у овом случају је коришћено неколико правила класификовања. 29

\section{КЛАСИЧНИ ЗАДАЦИ СТРАТЕГИЈЕ}

Када се разматрају теоријски ставови о задацима стратегије, на почетку могу да се наведу ставови о задацима војне стратегије, у које улази истраживање закономерности оружане борбе на основу теоретске анализе искуства из ратних дејстава стратегијских размера, узимајући у обзир садашње стање војног дела. Један од главних задатака стратегије јесте изучавање услова и карактера будућег рата и одређивање начина и форми његовог вођења. Полазећи од тога, стратегија мора одредити састав снага и средстава неопходних за постизање циљева који су пред њу постављени, па према томе, и општи правац развоја оружаних снага и њихове припреме за рат. У задатак стратегије, исто тако, спада разрада основа материјалног и техничког обезбеђења оружане борбе и руковођења оружаним снагама".30

Полазећи од задатака војне стратегије, аутори одређују питања која истражује теорија војне стратегије наводе: „Закономерности оружане борбе, услови и карактер будућег рата; теоретске основе припреме земље и оружаних снага за рат и принципи рата; видови оружаних снага и основе њихове стратегијске употребе; начелне одредбе цивилне одбране; начела вођења оружане борбе; основи материјалног и техничког обезбеђења оружане борбе; основе руковођења оружаним снагама ратом у целини; стратегијски погледи вероватног непријатеља“.31

Шапошњиков о војној стратегији каже: „Стратегија изучава основе припреме оружаних снага за рат и њихову мобилизацију, форме вођења рата и специфичности његовог планирања, основе одређивања главних стратегијских удара за сваки период рата, полазећи од политичког садржаја периода и

29 У поступку класификовања појма „стратегија државе“ коришћена су следећа правила: 1) јасно одређење обима тог појма; 2) за јединствени принцип класификације узето је једно својство (особина) као карактеристика за дату класу предмета; 3) класификација је потпуна, тј. није ни преширока ни преуска; 4) чланови деобе су прецизно и јасно разграничени и 5) род као заједничка особина у класификацији припада свим врстама које се под њега подводе (Зајечарановић, Г., Основи методологије науке, Научна књига, Београд, 1987, стр. 113).

30 Василиј Данилович Соколовски, Војна стратегија, друго допуњено издање, ВИЗ, Београд, 1965.

31 Исто. 
конкретне стратегијске ситуације... Одређивање основног правца на коме наношење главног удара може дати најбрже и најбоље резултате - најглавнији је задатак стратегије“.32 Семјонов о војној стратегији каже: „Стратегија се бави проучавањем и вођењем рата као оружане борбе у целини“.33

Даље, полазећи од циљева и карактера рата, аутори дела „О совјетској војној науци“, дефинишу задатке стратегије: „...изучавање оружаних снага евентуалних противника; помагање да се правилно одреди основни начин борбе, њени облици и општи замах; указивање на правце главних напора узимајући у обзир економске, моралне, војне и друге могућности; одређивање количине и квалитета неопходних средстава за постизање ратних циљева борбе, резерви свих врста, како материјално-техничких тако и живе силе; организација и припрема оружаних снага, ратишта и стратегијских праваца; разрада опших планова искоришћавања оружаних снага у рату, тј. општих стратегијских планова рата и његових кампања; планирање рата по етапама и друго“.34

На крају дела аутори закључују: „У општетеоријском делу, који се може назвати општетеоријским основама стратегије, истражује се - закони и принципи стратегије; теоријске основе разраде ратног плана; видови оружаних снага као стратегијске категорије, њихова својства примене у оружаној борби; начини и облици оружане борбе у стратегијском обиму; опште основе материјалног и техничког обезбеђења оружаних снага и опште основе управљања трупама у стратегијским размерама. У примењеном делу стратегија се бави разрадом конкретним питањима непосредне припреме и извођења ратних дејстава у стратегијском обиму, њиховог материјалног и техничког обезбеђења и конкретним питањима управљања стратегијским групацијама војске и оружаних снага у целини." 35

Анализирајући дела совјетских аутора може се закључити да су аутори у највећем делу сагласни су да војна стратегија проучава: закономерности оружане борбе у оквиру стратегије; услове и карактер будућег рата; теоријске основе припреме земље и оружаних снага за рат и принципе рата; видове оружаних снага и основе њихове стратегијске употребе; начелне одредбе цивилне одбране; начела вођења оружане борбе; основе материјалног и техничког обезбеђења оружане борбе; основе руковођења оружаним снагама и ратом у целини; стратегијски погледи потенцијалног непријатеља. У коначном, може се констатовати да војна стратегија проучава рат као тоталитет и све елементе војске која учествује у рату да би успешно спроводила политику којој је рат средство.

На основу анализе теоретичара о стратегији на Западу, може се закључити да је појам стратегија еволуирао после Другог светског рата, првенствено у нормама

\footnotetext{
32 Исто.

33 Митар Ковач, Божидар Форца, Историја ратне вештине, период 1920-2000, Београд, 2000.

34 Исто.

35 Исто.
} 
практичне делатности, теоријског одређења и садржаја стратегије, али да није било битних промена у односу на поставке стратегије које су дали Харт, Бофр, Фош, Фулер и други. Кад су у питању ставови српске војне мисли, озбиљније теоријско обликовање војне стратегије код нас почиње тек у делима генералштабног пуковника Живојина Мишића. У анализи Мишићевих ставова може се констатовати да је војна стратегија „вештина управљања војском на војишту“, а тактика „вештина вођења трупа на земљишту“.

У домаћој литератури јасно се издвајају ставови у вези војне стратегије, где се закључује да је то наука која изучава основне закономерности оружане борбе и рата, усмерава и координира остале научне дисциплине, посебно оператику и тактику. То је истовремено вештина усклађивања деловања војних, политичких, економских и моралних снага, елемент ратне вештине, који се бави теоријом и праксом, припремањем и вођењем рата и употребом оружане силе, систем научних знања и вештина (теорија и пракса) о припремању, вођењу рата и употреби силе. 36

\section{ДИНАМИЧНИ ПРИСТУП СТРАТЕГИЈЕ}

Класична теорија указује да ниједна стратегија и доктрина не може да се посматра одвојено. Оне се карактеришу својом динамиком и прилагођавањем другим, противничким стратегијама и доктринама, а воде се променама националних политика и уклапају се у стално ново динамично окружење које вишедимензионално утиче на све елементе стратегија и доктрина. ${ }^{37}$ Наведене одреднице указују на класичну, „рекативну“ и „последичну“ карактеристику стратегија и процеса њеног конципирања.

Са друге стране, поучени лошим ратним искуством из Другог светског рата, као и бројним концептуалним и оперативним недостацима у постојећим доктринарним документима и борбеним правилима, амерички стратези су почетком деведесетих година, у суштинском погледу, променили војно-политичку и стратешку филозофију САД. ${ }^{38}$ Циљ наведене промене филозофије стратегије био

36 Хајрадин Радончић, „Војна стратегија - покушај дефинисања појма“, Војно дело, 8/2017, стр 262-279.

37 Форца, Б.: Војни фактор међународних односа и његов утицај на развој Војске Југославије, докторска дисертација, ВА, Београд, 2003

38 За развој војно-стратешке мисли САД велики значај и допринос, а тиме и утицај, имали су почетком деведесетих година, поред војних стратега и планера, као што су Џозеф Нај, адмирал Виљем Оувенс, ранији заменик начелника здруженог састава САД, генерал Виљем Неш, генерал-потпуковник у пензији и директор Студија Хадсон института Виљем Одом, адмирал П. Милер, као плејада високо позиционираних генерала: Милер, Г. Саливан, Џон Фос, Џефри Ричелсон, Џон Саликашвили, начелник здруженог генералштаба САД, Мајкл Шмит, Џон Ронџу из Традоца, Максвел Тејлор, и тако даље. Такође, пресудни утицај испољили су и цивилни теоритичари и аналитичари међу којима се посебно истичу супружници Алвин и Хајди Тофлер, Елиот Кохен и други. 
је да се осигура глобална америчка доминација, кроз примену нове „стратегија обликовања окружења", ради промовисања америчких интереса. ${ }^{39}$

По оцени војних стручњака ван америчког војног естаблишмента, највећи искорак и допринос у војној стратешкој мисли представља револуционарни, у теорији и пракси, до сада непоновљив поступак израде стратешких докумената, а посебно њихов садржај. Наиме, користећи резултате револуције у војним пословима, амерички стратези су применили нови приступ израде доктринарних докумената и концепција који је заснован на новој филозофији, где је у прошлости развој био стратегије био последичан, а сада је динамичан. Нови приступ је по први пут примењен током израде борбеног правила ФМ 100-5 из 1993. године, да би био допуњен и конкретизован новим Упутством бр.525-5 који је објављен августа 1994. године у издању Команде за обуку копнене војске САД.40 Тадашњи амерички војни стратези су истицали да су „променили начин на који се мењамо“. У тој врло једноставној пропозицији садржана је целокупна војна филозофија, посебно у домену стратешког планирања. Наиме, САД од тог периода не чекају да технички, технолошки и друштвени развој својим квантитативним променама временом доведе до квалитативних промена стратегијске мисли, као што је то било раније, него овим приступом најпре планирају промене унапред, а то значи да креирају околности или амбијент у коме ће пројектовани задаци из стратегије бити лакше, брже и једноставније реализовани уз минималне губитке и нижу цену коштања. 41

Из управо наведеног аналитичког контекста, може се закључити да између тог приступа и изградње Новог светског поретка постоји аналогија у којој се настоји да се на глобалном плану створе услови у којима ће у будућности важити начела доктрине и стратегије које су амерички стратези предвидели остварити путем „меке“ и „тврде“ моћи, а у складу са унапред обликованим стратешким окружењем.

Другим речима, у свим стратешким концептима новијег датума, уграђена је могућност обликовања стратешког окружења односно конкретног стања на терену који значајно олакшава и омогућава остварење зацртаних стратешких циљева, укључујући и употребу војних ефектива уз минималне губитке и вођење рата по нижој цени.

Спецификум новог стратешког концепта садржан је у чињеници да САД изражавају спремност да имају сталну и потпуну иницијативу која подразумева промену начина на који се САД прилагођавају и начина на који САД мењају свет

39 Види: „Report of the Quadrennial Defense Review“, William S. Cohen Secretary of Defense,

May 1997, p. 74., Приступљено: 14. 08. 2020.

https://www.files.ethz.ch/isn/32542/qdr97.pdf

40 Милан Д. Живојиновић, Противречности стратегије сукоба ниског интензитета и међународног права у контексту сукоба у СФРЈ, докторска дисертација, Правни факултет, Београд, 2016, стр. 64-68.

41 Исто, стр 64. 
око себе. У том погледу настоје да управљају брзином промена тако да достигну жељене могућности, а да при томе не доведу у питање садашњу приправност.

Детаљнији увид у нову стратегију обликовања стратегијског окружења дали су веома исцрпно тадашњи шеф Пентагона, Вилијем Коен, и начелник здруженог генералштаба, генерал Шаликашвили, у четворогодишњем прегледу Одбране (ОДР 1997.) Такав приступ омогућио је постмодерној геополитици и геостратегији САД да целокупан глобални простор најпре зонира, затим мапира, форматизује и, на крају, јасно постави у географске оквире координате за будућа империјална наступања, освајања и стављања под контролу простора са природним и енергетским ресурсима. ${ }^{42}$

Кључни чинилац за примену наведене филозофије у изради и примени овакве стратегије је квалитативни скок и напредак на пољу информативне технологије и телекомуникација, укључујући и сателитску технологију, који је омогућио софистицирану примену новог начина вођења рата - „информационог ратовања“ за утицај на противничку страну, као и за обликовање стратегијског информационог окружења. У годинама које су следиле, војна штампа је била преплављена теоријама и научно-стручним радовима о информационом рату као важној компоненти сваког будућег рата.

Данас је порасла употреба информационих средстава за постизање политичких и стратешких циљева сукоба, и у многим случајевима је премашила моћ силе физичког оружја у његовој делотворности. ${ }^{43}$

Теоретичари због тога закључују да ће информационо ратовање имати кључну улогу у савременим и будућим конфликтима. ${ }^{44}$ Циљ у наредним ратовима неће бити постигнут уколико се не постигне информациона супериорност над противничком страном, односно док се не обликује информациона димензија стратегијског окружења у складу са стратегијским плановима.

Стратегија „обликовања окружења“ уз снажну примену информационог и пропагандног рата, као модел стварања оптималних услова за дејство у земљи жртви „унутрашње агресије“, у деведесетим година, била је тестирана и примењена у процесу разградње СФРЈ и агресије на СРJ. 45

42 Види: „Report of the Quadrennial Defense Review“, William S. Cohen Secretary of Defense, May 1997, p. 74. Приступљено: 14.08.2020. https://www.files.ethz.ch/isn/32542/qdr97.pdf

${ }^{43}$ Valery Gerasimov, "The Value of Science in Foresight: New Challenges Require Rethinking on the Forms and Methods of Warfare", Military Industrial Kurier, 27 Feb. 2013, Приступљено: 13.07.2020.

http://vpknews.ru/sites/default/files/pdf/VPK_08_476.pdf .

44 Sergei Chekinov, Sergei Bogdanov, "The Nature and Content of a New-Generation War, Voyenna

mysl,No.4,October2013,http://www.eastviewpress.com/Files/MT_FROM\%20THE\%20CURRE NT\%20ISSUE_No. 4_2013.pdf

45 Исто, стр 65. 


\section{СТРАТЕГИЈА ДЕТЕРМИНИСТИЧКОГ ХАОСА КАО ОБЛИК ДИНАМИЧНЕ СТРАТЕГИЈЕ}

Могло би се рећи да данас постоји општа сагласност да је „непредвидивост“ једна од константних одредница безбедносног окружења. Међу карактеристикама које трајно одликују ратове, као константе безбедносног окружења су: фрикција, хаос, опасност и стрес. Хаос представља једну од трајних карактеристика рата. Сукоб је, услед тога што представља деловање човека, увек неизвестан и хаотичан. ${ }^{46}$ Неизвесно информационо окружење у коме се дешавају савремени сукоби, настаје, између осталог, и због некомплетних, непрецизних или контрадикторних информација, доводи до стварања тзв. „магле рата“47, како каже Клаузевиц, што ограничава перцепцију и ствара конфузију код учесника сукоба.

Сагласно томе, у стратегијским документима из области безбедности и одбране, као и у анализама и проценама стратегијског окружења великог броја држава, неизвесност и непредвидивост се наводе као његове фундаменталне карактеристике.

Непредвидивост развоја светских догађаја подстакла је истраживаче да овом наведеном питању посвете више пажње, како би тим путем дошли до решења којима би се омогућило адекватније прилагођавања стално променљивим околностима у стратегијском окружењу.

Од креатора политике (стратега) и теоретичара стратегије (стратегичара) одувек се очекивало да разумеју велике научне и техничке промене и да на њих адекватно одговоре кроз формулисање и спровођење стратегија. У вези са тим, овде се већ може поставити питање, да ли је ефикасније и корисније трошити ресурсе на покушаје схватања стратегијске стварности, која је као што смо рекли непредвидива и пуна конфузије и хаоса, или заузети другачији приступ и своја средства усмерити на креирање стратегијског окружења у складу са својим геостратегијским циљевима. Циљ сваког од субјеката међународних односа јесте да избегне кризе и да истовремено одржи предвидивост свог окружења. Да би то постигли, неопходно је да реализују контролисану адаптацију, односно, потребно је да своје стратегије прилагоде окружењу. Уважавајући до сада наведене поставке, субјекти међународних односа имају на располагању следеће стратегијске опције:

- изградња таквог модела окружења чији ниво сложености могу да бирају,

- покушај да изврше утицај и контролу окружења, како би оно било предвидивије;

46 Nicholls, David, Todor Tagarev, „What Does Chaos Theory Mean for Warfare?“ Airpower Journal, Fall 1994,

http://www.airchronicles/apj/apj94/nichols.html. Приступљено: 13.06.2010

47 Видети: Карл фон Клаузевиц, О рату, ВИЗ, Београд: 1951. 
- избор врсте реда (поретка) који један од субјеката настоји да наметне динамици окружења, како би се постигла максимална предвидивост“. 48

C обзиром да постоје континуирани непредвидиви утицаји из спољашњег окружења, а исто тако и да противник такође утиче на окружење на непредвидив начин, сваки од субјеката међународних односа мора стално да ажурира своје стратегије.

Увиђајући наведени проблем у вези сложености савременог стратегијског окружења, као и да класични детерминизам није дао довољно употребљиве резултате за описивање, објашњавање и разумевање процеса који се одвијају у реалном свету, америчко спољно политичко руководство је крајем прошлог века иницирало рад на развоју савремених стратегијских инструмената и алата који би им омогућили контролисање криза у свету.

Истраживали су актере стратегијског окружења, начин на који остварују међусобне интеракције, као и параметре из спољног окружења који опредељујући утичу на њихове одлуке. Кључни помак остварен је истраживањем „концепта хаоса" и теорије детерминистичког хаоса која се бави проналажењем реда у привидном нереду и нереда у реду, што у извесној мери обезбеђује контролу ситуације. ${ }^{49}$

Очигледна практична примена резултата истраживања у области управљања процесима и догађајима у међународним односима, види се активностима администрације САД на плану уобличавања света по западном моделу и сходно његовим геополитичким потребама.

Са друге стране, уочава се да су и руски експерти из различитих области, интензивирали своју истраживачку делатност у тој области. Настоје да широј јавности учине транспарентним радове са којима разоткривају механизме који стоје иза стратегија тзв. „контролисаног хаоса“, или, како то у Руској Федерацији називају, „технологије контролисаног хаоса“ (технологии управляемого хаоса), коју САД користе за „демонтрирање“ појединих држава, сменом непослушних режима и успостављањем „кооперативних“ влада, што им олакшава остваривање пројектованих циљева. 50

Иначе, теорија о механизмима контроле хаоса говори да контрола процеса значи да ће познате намераване последице уследити након намерно изазваних

48 Наведено према: Mayer Kress, Gottfried. “Messy Futures and Global Brains,” Center for Complex Systems Research, Beckman Institute and Department of Physics, University of Illinois at Urbana Champaign, September 18, 1994. www.ccsr.illinois.edu/web/Techreports/1990-94/CCSR9426.pdf, p. 12. Приступљено 23.04.2012.

49 Бранкица Ђ. Поткоњак Лукић, Примена теорије детерминистичког хаоса на међународне односе после хладног рата, доктроска дисертација, Факултет политичких наука, Београд, стр 19.

50 Исто, стр 20. 
акција. ${ }^{51}$ Такође, говори се да хаос може бити погодан за постизање циљева контроле. 52 Потребно је једноставно сачекати да хаотично кретање доведе систем близу одговарајуће нестабилне периодичне орбите, када се почиње са опрезном и дозираном применом контроле. 53

Оно што је заједничко за стратегију детерминистичког хаоса са стратегијом обликовања окружења је да обе стратегије подразумевају примену извођење информационих и психолошких операција. ${ }^{54}$. Истраживањем ове теме у Русији се већ дужи низ година бави Андреј Манојло (Андрей Манойло Викторович), доктор политичких наука и професор Факултета политикологије Московског државног универзитета Ломоносов. Он наводи три основна концепта на којима се заснива примена „контролисаног хаоса“ који указују на повезаност са стратегијом обликовања окружења имплицира:

- „одржавање мира присилом“ (forceful peacekeeping) - успостављање, као приоритетног, начела употребе оружаних снага и других насилних метода за вршење притиска (укључујући и методе терористичког деловања од стране саме владе) са намером да се политички сукоби реше укључивањем арбитра, а то су (опет) САД;

- „мека сила“ или „извоз демократије“ - коришћење метода за насилну трансформацију политичке слике света како би она одговарала њиховим стандардима, као и усмерено коришћење информационих и психолошких технологија са циљем промене државног руководства „без употребе силе“ (плишане револуције) у земљама које нису спремне добровољно да следе америчку спољну политику;

- „униполарни свет“ - концепт креирања новог светског поретка и политичке ситуације у којој би, у међународним политичким процесима, улога УН и ОЕБС, као међународних организација чији је примарни задатак да пруже подршку безбедности и стабилности у међународним односима, била потпуно маргинализована, и у којој би они преузели решавање политичких сукоба у свету“. 55

Манојло сматра да сва три наведена концепта чине, по својој суштини, „класичне информационе и психолошке операције које се спроводе од стране пружања услуга, ради остваривања психолошке и информационе контроле над групном и појединачном свешћу становништва, непосредно у зони сукоба и изван њега“. 56

Као кључна начела на којима се заснива примена „контролисаног хаоса“ у изазивању обојених револуција ради обликовања стратегијског окружења,

\footnotetext{
51 Исто, стр.134.

52 Ott, E., Grebogi, C. and York, J. A. Controlling chaos. Physical Review Letters 64 (1990) 11961199.

53 Исто, стр.136.

54 Маноило, Андреи Викторович. „Models of Information and Psychological Operations Used in International Conflicts“, 2013. Приступљено 25.4.2020, Интернет: http://enotabene.ru/wi/article_9400.html

55 Исто.

56 Исто.
} 
идентификована су следећа: уједињавање различитих политичких група против п остојеће владе; подривање самопоуздања руководства земље и њихове уверености у лојалност војске; дестабилизација ситуације уз помоћ агресивних учесника протеста и криминалаца; обарање постојећег режима кроз државни удар или током тзв. „демократских избора“.57

Имајући у виду бројне грађанске ратове, кризе и „обојене револуције“ после хладног рата, до данас, не може се игнорисати чињеница да се пракса примене стратегије „контролисаног хаоса“ и информационог ратовања као његовог важног елемента, показала ефикасном у погледу геополитичког преобликовања света у корист до сада једине светске силе. ${ }^{58}$

\section{ЗАКЉУЧАК}

Живојин Мишић је у свом делу „Стратегија - вештина ратовања“ говорио да је „неоспорна истина да је историја ратова једино врело, из кога се црпу примери и начела у вештини ратовања“.59 Овим ставом нас Мишић не упућује на то да је „историја“ једини предмет стратегије, већ само „извор“ њеног проучавања. За даље разумевање предмета стратегије посебан значај има Свећинов став да се стратег бави будућношћу. Свећин наводи да све структурне елементе предмета стратегије потребно сагледавати у функцији будућности, имајући у виду актуелне сазнајне и искуствене претпоставке и уз уважавање прошлости. ${ }^{60}$ На овај начин Свећонов став можемо довести у везу и са опредељењем које се приписује Радомиру Путнику који каже да „право знање стратегије није у смислу теорије, него је право знање стратегије у способности да се проникне у стратегијску ситуацију“, чиме Путник фаворизује практични аспект стратегије, односно стратегију као вештину која је окренута будућност.

Са друге стране, када се узму у обзир ставови појединих теоретичара који говоре да је свака стратегија у ствари реактивна, пошто представља реакцију на спољно окружење и процес прилагођавања на измењену стратегијску околину, запажа се јака „реактивна особина“ класичне теорије и праксе стратегије.

Ако сумирамо горе наведене дефиниције и ставове, запажа се важност практичног аспекта стратегије, као процеса сталног прилагођавања променљивим условима и околностима у свету, у којем су шанса, несигурност и двосмисленост доминантни. Када се дода и став Молткеа да је стратегија “вештина делања под притиском и

\footnotetext{
${ }^{57}$ Shashkov, Sergei. The theory of "manageable chaos" put into practice, 2011. https://en.interaffairs.ru/article/the-theory-of-manageable-chaos-put-into-practice, Приступљено 06.09.2020.

58 Види шире: Миљковић Милан, „Информационе операције западних обавештајних служби у Србији октобра 2000. године“, Војно дело, 5/2017, стр. 98-108.

59 Мишић Живојин, Стратегија - вештина ратовања, Нова штампарија Давидовић, Београд, 1907, стр. X-XV.

60 Види шире у: Свећин, А., А., Стратегија, Војно дело, Београд, 1956.
} 
најтежих околности“, може се оценити да је стратегија државе пракса (вештина) непрекидног и упорног испуњавања националних циљева и интереса, и под под најтежим околностима, које су често несигурне, нејасне и двосмислене, тј прилагођавање метода испуњавања ових циљева услед промене услова и околности, како спољашњих тако и унутрашњих.

У овом процесу, улога стратегије је да уз помоћ теорије, праћењем и деловањем у циљу иницирања позитивних промена у стратешкој стварности, ствара повољне услове и користи шансе за реализацију циљева којима се испуњавају национални интереси. Улога стратегичара је да те шансе предвиди, уочи и да их предочи стратегу ради њиховог искориштења и обликовања стратегијске реалности коришћењем елемената националне моћи. Значи, како каже Едер (Erich Eder), стратегија је активност којом се предвиђени циљеви претварају прво у могућности а онда и у стварност. ${ }^{61}$ Наведена активност, коју Едер назива „претварање“, говори у ствари о важној улози стратегије као помоћног алата за обликовање стратегијске стварности.

Поента стратегије (барем оне квалитетне) није у сукобу, већ у победи која заобилази или маргинализује сукоб, дакле, свака примена насиља имплицира пораз стратегије. Без обзира да ли се ради о војној, политичкој или пословној стратегији, она је процес ширег и дубљег разматрања, темељне анализе и планирања решења неког проблема. Оно што је заједничко за стратегију детерминистичког хаоса и стратегије обликовања окружења је да и једна и друга подразумевају примену извођење информационих и психолошких операција у циљу обликовања стратегијског окружења, по могућству мирним путем, уз што мање ангажовање оружане силе.

Због тога је важно да стратегија не буде последична већ буде динамична, и да доприноси обликовању стратегијске стварности, у циљу стварања повољних услова за реализацију националних циљева мирним путем и уз максимално заобилажење сукоба. Тежити да се стратегија мање прилагођава окружењу, него да се више окружење прилагођава и обликује сходно циљевима стратегије. Трошити више ресурса на ресурсе на креирање стратегијског окружења у складу са својим геостратегијским циљевима, уз непрекидан напор да се схвати стратегијска стварност, која је непредвидива, пуна конфузије и хаоса.

\section{БИБЛИОГРАФИЈА}

1. „British Defence Doctrine“, MoD, Whitehall , London, 1996.

2. „Report of the Quadrennial Defense Review“, William S. Cohen Secretary of Defense, Мау 1997, Приступљено: 14.8.2020.

https://www.files.ethz.ch/isn/32542/qdr97.pdf

61 Erich Eder: Definition und Gebrauch des Begriffes «Strategie», Österreichische Militarische Zeitshrift, 2/98, s. 121-128. 
3. Berzins Janis, „Russia's New Generation Warfare”, The Potomac Foundation, October 11, 2016, http//www.thepotomacfoundation.org/The New Generation of Russian WarfareThe Potomac Foundation.htm

4. Brooks, R. E., War Everywhere: Rights, National Security Law and the Law of Armed Conflict in the Age of Terror, UPLR, Vol. 153, 675, 2004.

5. Chekinov Sergei, Bogdanov Sergei, "The Nature and Content of a New-Generation War,

Voyennamysl,No.4,October2013,http://www.eastviewpress.com/Files/MT_FROM\% 20THE\%20CURRENT\%20ISSUE_No. 4_2013.pdf

6. Eder, Erich: Definition und Gebrauch des Begriffes «Strategie», Österreichische Militarische Zeitshrift, 2/98, 1998.

7. Erich Eder: Definition und Gebrauch des Begriffes «Strategie», Österreichische Militarische Zeitshrift, 2/98.

8. Gerasimov Valery, "The Value of Science in Foresight: New Challenges Require Rethinking on the Forms and Methods of Warfare", Military Industrial Kurier, 27 Feb. 2013, Приступљено: 13.7.2020. http://vpknews.ru/sites/default/files/pdf/VPK_08_476.pdf .

9. Hartmann Uwe, The Evolution of the Hybrid Threat, and Resilience as a Countermeasure, NATO Defense College, Rome, Research Paper - No. 139 September 2017.

10. Hoffman Frank, "Conflict in the 21st Century: The Rise of Hybrid Wars," Potomac Institute for Policy Studies, Arlington, Virginia, December 2007, https://www.potomacinstitute.org/images/stories/publications/potomac_hybrid war_0108.pdf

11. Lucien Poirier. Essais de stratégie théorique, FEDN, Paris, 1982.

12. Mayer Kress, Gottfried. "Messy Futures and Global Brains," Center for Complex Systems Research, Beckman Institute and Department of Physics, University of Illinois at Urbana Champaign, September 18, 1994. Приступљено 23.04.2012 http://.ccsr.illinois.edu/web/Techreports/1990-94/CCSR- 94 26.pdf.

13. Nicholls, David, Todor Tagarev, „What Does Chaos Theory Mean for Warfare?" Airpower Journal, Fall 1994, Приступљено: 13.6.2010 http://www.airchronicles/apj/apj94/nichols.html.

14. Ott Edward, Grebogi Celso, James A. Yorke. Controlling chaos. Physical Review Letters 64, 1990.

15. Shashkov, Sergei. The theory of "manageable chaos" put into practice, 2011. https://en.interaffairs.ru/article/the-theory-of-manageable-chaos-put-intopractice/Приступљено 06.09.2020.

16. Бофр Анре, Увод у стратегију, ВИЗ, Београд, 1968.

17. Викторович Андреи Маноило, „Models of Information and Psychological Operations Used in International Conflicts“, 2013. Приступљено 25. 4.2020., http://e-notabene.ru/wi/article_9400.html

18. Вишњић Душан, „Општа стратегија или стратегија државе - нације“, Војно дело, зима/2011, Београд, 2011.

19. Војна енциклопедија, друго издање, ВИЗ, Београд, 1975, стр. 171.

20. Едвард Меад Ерл, Творци модерне стратегије, Војно дело, Београд, 1952.

21. Живојин Мишић, Стратегија - вештина ратовања, 1907, Нова штампарија Давидовић, Београд. 
22. Живојиновић Д Милан, Противречности стратегије сукоба ниског интензитета и међународног права у контексту сукоба у СФРЈ, докторска дисертација, Правни факултет, Београд, 2016.

23. Зорић Миланко, „Теоријске основе опште стратегије“, Војно дело, 1/99.

24. Иветић Велимир, Политичка улога министара војних Краљевине Србије од 1903. до 1914. године, доктроска дисертација, Факултет политичких наука Београд, 2013.

25. Клаузевиц фон Карл, О рату, ВИЗ, Београд: 1951.

26. Кнежевић-Предић Весна, Нови ратови v. старо право, Извод из књиге: Оглед о међународном хуманитарном праву, Чигоја штампа, Београд, 2007, Приступљено: 14.08.2020., https://www.rastko.rs/rastko/delo/14837

27. Ковач Митар, Божидар Форца, Историја ратне вештине, период 1920-2000, Београд, 2000.

28. Лидел Харт, Стратегија посредног прилажења, Војно дело, Београд, 1952.

29. Маладох , Лист Ратник, Година LXXI, Свеска 1, Август 1911.

30. Миљковић Милан, „Информационе операције западних обавештајних служби у Србији октобра 2000. године“, Војно дело, 5/2017, Београд, 2017.

31. Мишић Живојин, Стратегија - вештина ратовања, Нова штампарија Давидовић, Београд, 1907.

32. Поткоњак Лукић Бранкица, Примена теорије детерминистичког хаоса на међународне односе после хладног рата, докторска дисертација, Факултет политичких наука, Београд, 2015.

33. Радончић Хајрадин, „Војна стратегија - покушај дефинисања појма“, Војно дело, 8/2017, Београд, 2017.

34. Савић Сава, Стубови европске безбедности на почетку 21. века - НАТО и Европска унија, Медија Центар Одбрана, Београд, 2013.

35. Свећин, А., А., Стратегија, Војно дело, Београд, 1956.

36. Соколовски Василиј Данилович, Војна стратегија, друго допуњено издање, ВИЗ, Београд, 1965.

37. Форца Божидар, Војни фактор међународних односа и његов утицај на развој Војске Југославије, докторска дисертација, ВА, Београд, 2003.

\section{NEW WARS AND CHALLENGES OF CLASSICAL STRATEGIC THOUGHT}

The recent conflicts were something completely new in the practice of waging wars, which influenced the scientific public to start a discussion about a new definition of the very concept and characteristics of modern warfare. Consequently, in modern military theory, there are such definitions that classify wars into traditional and non-traditional, ie they speak of a "new generation of warfare" in which armed struggle is not its obligatory attribute. These theories of the "new war" have attracted many supporters, but have also opened up new questions, as they have, among other things, made existing international humanitarian law obsolete and unusable. The strategy, scientific theory and practice of the highest state and military importance, which should provide guidance and create conditions for the realization of political, economic and defense interests of the nation, were also challenged. The priority tasks of strategy as a science continue to be the research of new forms of confrontation between states, as well as the 
elaboration of effective ways of opposing them, the creation of scenarios and long-term forecasts for the development of the strategic situation. On the other hand, for a long time in Western strategic thought, under the influence of the military-technological revolution, there has been a new approach to formulating new matrices in strategic frameworks. In this regard, a research question can be asked: is it more efficient to apply an approach based on a new philosophy and a dynamic approach during the development and implementation of strategic documents. A comparative analysis of the features of "classical" strategic thought and the determinants of certain new American military strategies and the strategy of deterministic chaos, indicates that shaping strategic reality is a more important role of strategy than forecasting features and methods of defense in future conflicts.

Keywords: classical strategy, dynamic strategy, shaping of strategic reality 